\title{
SOME PROPERTIES OF DUAL FORM OF THE HAMY'S SYMMETRIC FUNCTION
}

\author{
WEI-DONG JIANG
}

Abstract. The Schur-concavity and the Schur-geometrically convexity of dual form for the Hamy symmetric function are discussed and some analytic inequalities are established by use of the theory of majorization.

Mathematics subject classification (2000): 26D07, 26D15.

Key words and phrases: Dual form, Hamy's symmetric function, Schur-convexity, Schur-geometrically convexity, inequality.

\section{REFERENCES}

[1] Kaizhong Guan, The Hamy Symmetric Function And Its Generalization. Math. Inequal. Appl., Volume 9, Number 4 (2006), 797-805.

[2] B.-Y. WANG, Foundations of majorization inequalities, Beijing Normal Univ. Press, Beijing, China, 1990 (Chinese)

[3] T. HARA, M. UCHIYAMA AND S. TAKAHASI, A refinement of various mean inequalities, J. Inequal. Appl., 2 (1998), 387-395.

[4] J. C. KuANG, Applied Inequalities (3nd ed.), Shandong Science and Technology Press, Jinan, 2004

[5] A. W. MARShall AND I. OlKIn, Inequalities: Theory of Majorization and Its Applications, Academic Press, New York, 1979.

[6] G. H. HARDY, J. E. LitTlewood AND G. PólYa, Some simple inequalities satisfied by convex functions, Messenger Math., 58 (1929), 145-152.

[7] D. S. Mitrinović, Analytic Inequalities, Springer-Verlag, New York, 1970.

[8] C. P. NiCULESCU, Convexity according to the geometric mean, Math. Inequal. Appl. 2 (2000) 155-167.

[9] Xiao-Ming Zhang, Geometrically-Convex Functions, Anhui Univ. Press, Hefei, 2004 (in Chinese).

[10] HUAN-NAN SHI, Majorized proof of a kind of inequalities for symmetric function (in Chinese), Chinese J. Math. for Techology, 15 (3) (1999), 140-142. 